\title{
Biological Control of Fusarium Seedling Blight Disease of Wheat and Barley
}

\author{
Mojibur R. Khan, Sven Fischer, Damian Egan, and Fiona M. Doohan
}

Molecular Plant-Microbe Interactions Laboratory, Department of Environmental Resource Management, Faculty of Agri-Food and the Environment, University College Dublin, Belfield, Dublin 4, Ireland. Accepted for publication 21 December 2005.

\begin{abstract}
Khan, M. R., Fischer, S., Egan, D., and Doohan, F. M. 2006. Biological control of Fusarium seedling blight disease of wheat and barley. Phytopathology 96:386-394.

Fusarium fungi, including $F$. culmorum, cause seedling blight, foot rot, and head blight diseases of cereals, resulting in yield loss. In a screen for potential disease control organisms and agents, Pseudomonas fluorescens strains MKB 100 and MKB 249, P. frederiksbergensis strain 202, Pseudomonas sp. strain MKB 158, and chitosan all significantly reduced the extent of both wheat coleoptile growth retardation and wheat and barley seedling blight caused by F. culmorum (by 53 to 91\%). Trichodiene synthase is a Fusarium enzyme necessary for trichothecene mycotoxin biosynthesis; expression of the gene encoding this enzyme in wheat was $33 \%$

lower in stem base tissue coinoculated with Pseudomonas sp. strain MKB 158 and $F$. culmorum than in wheat treated with bacterial culture medium and $F$. culmorum. When wheat and barley were grown in soil amended with either chitosan, $P$. fluorescens strain MKB 249, Pseudomonas sp. strain MKB 158, or culture filtrates of these bacteria, the level of disease symptoms on $F$. culmorum-inoculated stem base tissue (at 12 days postF. culmorum inoculation) was $\geq 31 \%$ less than the level on F. culmoruminoculated plants grown in culture medium-amended soil. It seems likely that at least part of the biocontrol activity of these bacteria and chitosan may be due to the induction of systemic disease resistance in host plants. Also, in coinoculation studies, Pseudomonas sp. strain MKB 158 induced the expression of a wheat class III plant peroxidase gene (a pathogenesisrelated gene).
\end{abstract}

Fusarium fungi, including $F$. culmorum, $F$. graminearum, $F$. poae, and $F$. avenaceum, cause seedling blight, foot rot, and head blight diseases of cereals, resulting in yield loss (33). Fusarium head blight (FHB) is a major cereal disease worldwide which can result in mycotoxin contamination of grains (37). Seedling blight and foot rot cause extensive damage to growing seedlings (45) and lead to a reduction in plant establishment, number of heads per square meter, and grain yield $(24,46)$. Because of the risk of mycotoxin contamination of grain, control of FHB of cereals has received more attention than control of seedling blight and foot rot diseases caused by Fusarium species. Pesticide use as a seed treatment has been shown to be effective in reducing the seedborne inocula of Fusarium (40), but toxic residues associated with fungicides can be problematic. Commercial cereal cultivars with high resistance to Fusarium diseases are not yet available (4).

Biological control involving microbial agents or biochemicals to control plant pathogens can be an eco-friendly and cost-effective component of an integrated disease management program (29). In wheat, seed treatment with several bacteria, including fluorescent pseudomonads, Pantoea sp., Bacillus cereus, and the fungus Trichoderma harzianum, has shown promise for control of $\mathrm{Fu}-$ sarium seedling blight caused by $F$. graminearum, F. culmorum, and Microdochium nivale in glasshouse and field studies $(4,25)$. Many studies have shown that fluorescent pseudomonads, Pantoea sp., Bacillus spp., and T. harzianum are among the most effective microbes in controlling a range of soilborne diseases $(7,25,38)$. The biological control ability of selected fluorescent Pseudomonas spp. can be the result of competition for nutrients and space, siderophore-mediated competition for iron, antibiosis, or induc-

Corresponding author: M. R. Khan; E-mail address: mrk6@ rediffmail.com

DOI: 10.1094/PHYTO-96-0386

(c) 2006 The American Phytopathological Society tion of induced systemic resistance in the host plant $(2,6,35)$. Strains of Pantoea sp. antagonize by means of chitinolytic enzymes, while strains of some Bacillus spp. have the ability to secrete chitinolytic enzymes and to induce systemic resistance in the host plant (43). Trichoderma spp. have been reported to compete for nutrients, secrete antifungal compounds, parasitize fungal pathogens, and induce systemic resistance in the host plant (44). Biochemicals such as salicylic acid, probenazole (Oryzemate), $\beta$ amino butyric acid, 2,6-dichloroisonicotinic acid, benzo (1,2,3)thiadiazole-7-carbothiolic acid (BTH), riboflavin, and chitosan have been shown to induce systemic plant defense against different pathogens (19). However, the only commercial product available for inducing systemic resistance, benzo $(1,2,3)$-thiadiazole-7carbothiolic S-methyl ester (BTH) (Novartis Crop Protection), was ineffective in controlling FHB disease of wheat studied under controlled environment conditions (47). Chitosan is a deacetylated derivative of crab-shell chitin that can activate host defense mechanisms. It possesses direct antimicrobial activity against some fungi and bacteria (43). In agriculture, chitosan has been utilized as a soil amendment and foliar spray against plant pathogens (20). It controlled infection of wheat seeds caused by $F$. graminearum under in vitro conditions (40).

Lack of both stable formulations and knowledge of microbial adaptation to different environments means that the potential of biocontrol agents to control disease under field conditions has not been fully exploited (17). In this respect, formulations based on spores of gram-positive microorganisms such as Bacillus spp. and Streptomyces spp. have advantages over gram-negative bacteria such as Pseudomonas, as they can withstand heat and desiccation stress (17). Vermiculite-based formulations have been shown to increase the survival rate of the biocontrol bacterium Pseudomonas sp. (31). The addition of chitosan to a formulation of B. pumilus increased the effectiveness of this bacterium in controlling Fusarium wilt of tomato (5). Also, intraspecific communication between biocontrol $P$. putida strains increased their biocontrol 
activity (14). Therefore, combining different biocontrol bacteria may increase disease control efficacy.

In this study, 151 bacterial and 31 fungal isolates collected from Irish cereal fields were evaluated, along with chitosan, for their ability to inhibit Fusarium seedling blight disease of wheat and barley caused by F. culmorum by in vitro and in planta tests. The F. culmorum Tri5 gene codes for trichodiene synthase which catalyses the first step of the trichothecene biosynthetic pathway (23). The effect of the potential biocontrol agent Pseudomonas sp. strain MKB 158 on Tri5 gene expression during F. culmorum pathogenesis of wheat was investigated. The mode of action of potential biocontrol agents was assessed. The ability of potential biocontrol agents to induce the expression of a wheat pathogenesis-related peroxidase gene during $F$. culmorum infection also was studied.

\section{MATERIALS AND METHODS}

Fungi, bacteria and bacterial culture filtrate. The Fusarium isolates used in this study included $F$. culmorum strain FCF 200 (UK), F. graminearum strain HUGR9 (Hungary), and F. poae strain HUPO3 (Hungary). Fungal mycelia were stored at $-70^{\circ} \mathrm{C}$ in $10 \%$ (vol/vol) glycerol. Prior to use, the Fusarium isolates were subcultured onto potato dextrose agar (PDA) (Scharlau Chemie, Barcelona, Spain) plates and incubated at $25^{\circ} \mathrm{C}$ for 7 days. Conidial inocula were produced in Mung bean broth (9), and adjusted to a final concentration of $2 \times 10^{6} \mathrm{ml}^{-1}$ with $0.2 \%$ Tween 20 . Mycelial inoculum was produced as described by Brennan et al. (10) and adjusted to a final concentration of $8 \mathrm{mg}$ of mycelial homogenate $\mathrm{ml}^{-1}$ of sterile distilled $\mathrm{H}_{2} \mathrm{O}$.

The 151 bacterial and 31 fungal isolates tested for biocontrol potential were obtained from cereal plant and soil samples collected from five Irish counties (Donegal, Louth, Galway, Kildare, and Tipperary); bacterial identity was determined using morphological characteristics and $16 \mathrm{~S}$ rRNA sequence analysis, and fungi were identified using morphological characteristics (M. R. Khan, D. Egan, B. Fagan, and F. M. Doohan, unpublished data). Pseudomonas spp. were grown on King's B agar (27) to determine if they produced fluorescent pigments. The bacterial isolates were stored at $-70^{\circ} \mathrm{C}$ in Luria-Bertani (LB) broth (41) in $10 \%$ ( vol/vol) glycerol. Bacterial isolates were subcultured onto nutrient agar (Oxoid Ltd., Hampshire, England) and incubated at $25^{\circ} \mathrm{C}$ for 3 days. Inoculum was produced by transferring a loopful of bacteria into $100 \mathrm{ml}$ of LB broth (in a 300-ml conical flask) and incubating at $25^{\circ} \mathrm{C}$, with shaking $(180 \mathrm{rpm})$ for $24 \mathrm{~h}$. Depending on the experiment, the inoculum was adjusted to $\log \mathrm{CFU} \mathrm{ml} \mathrm{m}^{-1}=2.8$ to 7.0. Filtrate was obtained by filtering cultures $\left(\log \mathrm{CFU} \mathrm{ml} \mathrm{l}^{-1}=\right.$ 7.0) through $0.2 \mu \mathrm{m}$ nitro-cellulose filters (Millipore Corp., Billerica, MA). Fungal isolates were maintained as described above for Fusarium. Prior to use, they were subcultured onto PDA and inoculated at $25^{\circ} \mathrm{C}$ with $12 \mathrm{~h}$ light/ $12 \mathrm{~h}$ dark cycles for 7 days to promote sporulation. Spores were scraped from the culture surface with a glass slide, homogenized in sterile distilled water, and filtered through double layers of sterile J-cloth (Johnson \& Johnson, Dublin, Ireland), and the concentration was adjusted to $1 \times 10^{6}$ spores $\mathrm{ml}^{-1}$ of sterile distilled $\mathrm{H}_{2} \mathrm{O}$.

Plant material. The wheat cultivars used in this study were the hard red winter wheat 'GK-Othalom' (supplied by Lazlo Hornok, Agricultural Biotechnology Centre, Godollo, Hungary), the soft red winter wheat 'Marshal', the hard white winter wheat 'Soisson', the soft white winter wheats 'Access' and 'Claire', and the soft white spring wheat 'Baldus' (supplied by Goldcrop, Seedtech and Powerseeds, Cork, Ireland). The two-row barley cv. Lux was supplied by Powerseeds, Kildare, Ireland.

Preparation of chitosan. Chitosan extract from crab shells (85\% deacetylated; Cat. no. C-3646, Sigma Chemical, St. Louis) was solubilized in $0.5 \mathrm{M}$ aqueous acetic acid $\left(3 \mathrm{mg} \mathrm{ml}^{-1}\right)$. The solution was then alkalized to $\mathrm{pH} 5.2$ with $1 \mathrm{~N} \mathrm{KOH} \mathrm{(48)} \mathrm{and}$ autoclaved at $15 \mathrm{psi}$ for $15 \mathrm{~min}$. Aqueous acetic acid $(0.5 \mathrm{M})$ alkalized with $1 \mathrm{~N} \mathrm{KOH}$ to $\mathrm{pH} 5.2$ served as the control for all treatments involving chitosan.

In vitro seedling germination tests. A previously described in vitro seedling test $(10,30)$ was used to test the ability of the 151 bacteria, 31 fungi and chitosan to ameliorate the effect of $\mathrm{Fu}$ sarium on seedling germination of wheat cv. GK-Othalom. The test was modified in that surface-sterilized wheat seeds (16 per plate) were incubated in either bacterial inoculum $\left(\log \mathrm{CFU} \mathrm{ml} l^{-1}=\right.$ $2.8)$, chitosan $(1,000 \mathrm{ppm})$, fungal spore inoculum $\left(1 \times 10^{6}\right.$ spores $\mathrm{ml}^{-1}$ ), or control solutions (LB broth, alkalized acetic acid, or $0.2 \%$ Tween 20) for $2 \mathrm{~h}$. These seeds were air-dried for $30 \mathrm{~min}$ and 20 seeds were placed on PDA plates overlayed with either mycelial homogenate of $F$. culmorum strain FCF 200 or $0.2 \%$ Tween 20 (negative control plates). The plates were incubated at $24^{\circ} \mathrm{C}$ in darkness. Coleoptile length was measured after 48 and $72 \mathrm{~h}$ and the growth rate of seedlings was determined (millimeter per day). The growth rate of seedlings treated with bacteria, fungi, or chitosan and incubated on Fusarium mycelium homogenate was determined as a percentage of the growth of seedlings treated with control solutions (LB broth, alkalized acetic acid, or $0.2 \%$ Tween 20, respectively) and incubated on $0.2 \%$ Tween 20 . This screening experiment was conducted once and included two replicates per treatment combination, arranged in a randomized design. The 15 microbial isolates that showed the most potential in the screening experiment to ameliorate the effect of F. culmorum on coleoptile growth of 'GK-Othalom' were then subjected to further seed germination tests to verify the screening results and to analyze the effect of wheat cultivar on their performance. These tests were conducted as described above, using wheat seed of 'GK-Othalom', 'Marshal', 'Access', 'Soisson', 'Claire', and 'Baldus'. We also assessed the ability of these 15 bacteria to colonize the surface of wheat seeds (cv. GK-Othalom). The test was conducted similar to the seed germination test, except that there was no Fusarium inoculum and bacteria-treated seeds were placed on sterile filter paper overlaying PDA plates. Seeds were surface-sterilized and treated with bacteria as described above for the seedling germination tests. After 6 and $24 \mathrm{~h}$ incubation at $24^{\circ} \mathrm{C}$, bacteria were washed from the surface of seeds using $1 \mathrm{ml}$ of $0.9 \%$ (wt/vol) $\mathrm{NaCl}$ and the log CFU per seed was determined with serial dilution pour plating technique (11). With the exception of the screening experiment, each experiment was conducted twice and included three replicate plates per treatment combination per harvest time point in a randomized design.

Stem inoculation seedling blight tests. The effect of seven bacteria (unidentified isolate MKB 25, P. fluorescens strain MKB 100, Acinetobacter sp. strain MKB 121, Pseudomonas sp. strain MKB 158, P. frederiksbergensis strain MKB 202, P. fluorescens strain MKB 249, and Chryseobacterium sp. strain MKB 277) and chitosan on Fusarium seedling blight was assessed using a modified method of Doohan et al. (16). The stem bases of 10-dayold seedlings of wheat (cv. GK-Othalom) and barley (cv. Lux) grown in John Innes compost No. 1 (Westland Horticulture, Dungannon, UK) were inoculated with a $400-\mu$ mixture of $F$. culmorum strain FCF 200 conidial suspension $\left(1 \times 10^{6}\right.$ spores $\mathrm{ml}^{-1}$, $0.2 \%$ Tween 20 ) and 24-h-old bacterial cultures $\left(\log \mathrm{CFU} \mathrm{m} \mathrm{m}^{-1}=\right.$ $7.0)$ or chitosan $(1,000 \mathrm{ppm})$ in $1 \%$ agar (Difco Laboratories, Detroit, MI). Stem bases were placed inside a 2-cm length of sterile silicon tubing $(0.5-\mathrm{cm}$ diameter). Controls included plants treated with $1 \%$ agar that contained either $F$. culmorum conidia plus LB broth or $0.2 \%$ Tween 20 plus bacterial inoculum. The plants were grown in a climate-controlled growth room with day/night temperatures of $20 / 12^{\circ} \mathrm{C}$, with a 12 -h light period $\left(700 \mu \mathrm{mol} \mathrm{m} \mathrm{m}^{-2} \mathrm{~s}^{-1}\right)$ and constant humidity of $85 \%$. Visible disease symptoms on the stems were scored at 12 days postinoculation using the disease scoring system described by Nicholson et al. (32). Seedling blight disease scores were the product of lesion length (centimeters) by lesion color (lesion color scale: 0 , no 
disease; 1 , very slight brown necrosis; 2 , slight/moderate brown necrosis; 3 , extensive brown necrosis; and 4, extensive black necrosis). This experiment was conducted twice and included three replicate pots (each containing two plants) per treatment combination in a randomized design.

Soil inoculation seedling blight tests. The bacteria Pseudomonas sp. strain MKB 158 and P. fluorescens strain MKB 249 and chitosan were selected for soil inoculation seedling blight tests based on their performance in stem inoculation seedling blight tests. Pots were prepared containing $145 \mathrm{~g}$ of John Innes compost No. 1 amended with $10 \mathrm{ml}$ of either 24-h-old bacterial cultures ( $\left.\log \mathrm{CFU} \mathrm{m} \mathrm{l}^{-1}=7.0\right)$, culture filtrate, chitosan $(1,000 \mathrm{ppm})$ alone or in different combinations. Control soils were amended with $10 \mathrm{ml}$ of either LB broth or alkalized acetic acid. Pots were placed at $20^{\circ} \mathrm{C}$, and after $24 \mathrm{~h}$, seeds of wheat (cv. GK-Othalom) and barley (cv. Lux) (pregerminated on moist filter paper, as described by Doohan et al. [16]) were planted into the soils. Plants were incubated in non-climate-controlled glasshouse and, after 10 days, were inoculated with conidial suspensions of $F$. culmorum strain FCF 200 or $0.2 \%$ Tween 20 (negative control). Visual disease symptoms were assessed 12 days postinoculation, as described above for stem inoculation seedling blight tests. This experiment was conducted twice and included three replicate pots (each containing two plants) per treatment combination in a randomized design.

Dual culture plate tests. Dual culture plate tests were performed for the 15 bacteria that showed the most potential to ameliorate the effect of $F$. culmorum in seed germination tests (Tables 1 and 2). These tests were performed using a modification of the method described by Pedersen et al. (34). Each PDA plate was inoculated with a mycelial plug $(0.5-\mathrm{cm}$ diameter $)$ from a 7-day-old PDA culture of either F. culmorum strain FCF 200, $F$. graminearum strain HUGR9, or $F$. poae strain HUPO3 and incubated at $25^{\circ} \mathrm{C}$ in darkness. After $24 \mathrm{~h}, 1 \mu \mathrm{l}$ of either bacterial suspension ( $\log \mathrm{CFU} \mathrm{ml} \mathrm{m}^{-1}=7.0$ ) or LB broth (control) was placed $4 \mathrm{~cm}$ from the growing Fusarium mycelial plugs. Plates were again incubated at $25^{\circ} \mathrm{C}$ in darkness. Fusarium colony diameter was measured after 3,4 , and 5 days and used to determine the growth rate (millimeters per day) of dual culture plates, relative to that of Fusarium cultures grown in the presence of LB broth. This experiment was conducted twice and included three replicate PDA culture plates per treatment combination in a randomized design.

Chitosan growth inhibition tests. The effect of chitosan was tested using paper disk, agar diffusion, and media incorporation tests to determine if it possessed direct antifungal activity against
Fusaria. For all three tests, growth was measured as described for dual culture tests, and each experiment was conducted twice and included three replicate PDA culture plates per treatment combination. For paper disk tests, Fusaria were cultured on PDA as described for dual culture tests, and after $24 \mathrm{~h}$, autoclaved $0.5-\mathrm{cm}$ diameter filter paper disks (Whatman No. 1, Whatman International Ltd., Maidstone, UK) were dipped in either chitosan (1,000 ppm) or alkalized acetic acid and placed $4 \mathrm{~cm}$ from the growing Fusarium mycelial plugs. Plates were again incubated at $25^{\circ} \mathrm{C}$ in darkness. Agar diffusion tests were as described for dual culture tests, except that, as opposed to coinoculation, wells $(0.5-\mathrm{cm}$ diameter) were bored in 24-h-old Fusaria cultures $4 \mathrm{~cm}$ from the mycelial plug and the wells were filled, and topped up every $12 \mathrm{~h}$, with either chitosan $(1,000 \mathrm{ppm})$ or alkalized acetic acid. Medium incorporation tests were also as described for dual culture tests, except chitosan $(1,000 \mathrm{ppm})$ or alkalized acetic acid were mixed $(1: 1)$ with cooled PDA $\left(50^{\circ} \mathrm{C}\right)$ before pouring and one mycelial plug $(0.5-\mathrm{cm}$ diameter) of the Fusarium isolates was inoculated at the center of the plate. This experiment was conducted twice and included three replicate PDA culture plates per treatment combination in a randomized design.

Gene expression studies. Reverse transcriptase-polymerase chain reaction (RT-PCR) analysis was used to analyze (i) the effect of P. fluorescens strain MKB 156 and Pseudomonas sp. strain MKB 158 on the expression of a class III peroxidase gene $(P O X)$ (which is a pathogenesis-related protein known to be upregulated in wheat in response to fungal pathogens [K. I. Ansari and F. M. Doohan, personal communication]); and (ii) the effect of Pseudomonas sp. strain MKB 158 on Fusarium trichodiene synthase (Tri5) gene expression during pathogenesis of wheat seedlings. Trichodiene synthase is a key enzyme necessary for the synthesis of trichothecene mycotoxins (23). The RNA was extracted from plants in the stem inoculation seedling blight tests 12 days after fungal inoculation. Freeze-dried samples were ground to a fine powder with liquid $\mathrm{N}_{2}$ and a pestle and mortar. Total RNA was extracted from the resulting powder using the protocol described by Chang et al. (12) and treated with DNase1 according to the manufacturer's instructions (Invitrogen Corp., Carlsbad, CA). The resulting RNA was resuspended and diluted in diethyl pyrocarbonate (DEPC)-treated water to a final concentration of $125 \mathrm{ng}^{-1} \mathrm{l}^{-1}$. The RT-PCR analyses were performed and products were analyzed as described by Doohan et al. (16); $P O X$ was co-amplified with glyceraldehyde-3-phosphate dehydrogenase $(G A P D H)$ and Tri5 with $\beta$-tubulin, and the expression of the gene of interest was normalized, relative to that of the housekeeping GAPDH or $\beta$-tubulin gene. Gene-specific forward

TABLE 1. Effect of bacteria on coleoptile growth of Fusarium culmorum-infected seeds

\begin{tabular}{|c|c|c|c|c|c|c|c|}
\hline \multirow[b]{2}{*}{ Treatment } & \multirow[b]{2}{*}{ Bacterial species $^{\mathrm{a}}$} & \multicolumn{6}{|c|}{ Coleoptile growth rate of Fusarium-inoculated wheat seeds $(\%)^{\mathrm{b}}$} \\
\hline & & GK-Othalom & Access & Marshal & Claire & Soisson & Baldus \\
\hline FCF $200+$ LB broth & $\ldots$ & 0 & 0 & 0 & 0 & 0 & 0 \\
\hline FCF $200+$ MKB 25 & ND & 47 & 35 & 96 & 30 & 95 & 85 \\
\hline FCF $200+$ MKB 41 & Exiguobacterium sp. & 49 & 0 & 13 & 14 & 0 & 11 \\
\hline FCF $200+$ MKB 55 & $\mathrm{ND}$ & 23 & 0 & 0 & 0 & 0 & 0 \\
\hline FCF $200+$ MKB 74 & Low $\mathrm{G}+\mathrm{C}$ gram-positive bacterium & 30 & 14 & 46 & 13 & 11 & 13 \\
\hline FCF $200+$ MKB 85 & Bacillus mycoides & 26 & 0 & 13 & 0 & 11 & 7 \\
\hline FCF $200+$ MKB 90 & Pseudomonas fluorescens & 58 & 0 & 0 & 0 & 0 & 18 \\
\hline FCF $200+$ MKB 100 & P. fluorescens & 26 & 14 & 49 & 75 & 55 & 30 \\
\hline FCF $200+$ MKB 121 & Acinetobacter sp. & 56 & 14 & 53 & 60 & 50 & 45 \\
\hline FCF $200+$ MKB 156 & P. fluorescens & 32 & 0 & 0 & 0 & 0 & 0 \\
\hline FCF $200+$ MKB 158 & Pseudomonas sp. & 42 & 37 & 89 & 55 & 62 & 77 \\
\hline FCF $200+$ MKB 159 & ND & 36 & 0 & 0 & 0 & 0 & 0 \\
\hline FCF $200+$ MKB 202 & P. frederiksbergensis & 92 & 25 & 13 & 35 & 25 & 32 \\
\hline FCF $200+$ MKB 249 & P. fluorescens & 60 & 29 & 30 & 17 & 25 & 15 \\
\hline FCF $200+$ MKB 264 & ND & 31 & 0 & 13 & 0 & 21 & 9 \\
\hline FCF $200+$ MKB 277 & Chryseobacterium sp. & 37 & 12 & 40 & 42 & 44 & 15 \\
\hline
\end{tabular}

a Identified based on partial $16 \mathrm{~S}$ rDNA sequence. ND = not determined.

${ }^{\mathrm{b}}$ Growth rate of seedling coleoptiles, relative to that of control seedlings treated with $0.2 \%$ Tween 20 and Luria-Bertani $(\mathrm{LB})$ broth. $\mathrm{LSD} \mathrm{D}_{0.05}=4$. 
and reverse primers used were $P O X, 5^{\prime}$-AGGCTAAAGATTGCCGTCAC-3' and 5'-GCGTCTAGCTCCAGGACAGT-3'; GAPDH, 5'-GTTTCCCTCAGACTCCTCCTT-3' and 5'-TAACTGCCTTGCTCCTCTTGCT-3'; Tri5, 5'-AGCGACTACAGGCTTCCCTC-3' and $5^{\prime}$-AAACCATCCAGTTCTCCATCTG-3'; and $\beta$-tubulin, $5^{\prime}$ ATGGCCTGCTGTCTCATGTA- ${ }^{\prime}$ and $5^{\prime}$-CCTGGTGGCTGGTAGTTGAT-3' (16) (K. I. Ansari and F. M. Doohan, personal communication). All gene expression studies were based on two seedling blight experiments, each of which included three replicate RNA extracts (each extracted from two plants) per treatment combination.

Statistical analysis. All data, except stem inoculation seedling blight tests and soil inoculation seedling blight tests, were normally distributed, as determined using the Ryan Joiner normality test within MINITAB (Minitab release 13.32, 2000; Minitab Inc., State College, PA) (42). Data from soil inoculation seedling blight test were normalized using the Johnson transformation within MINITAB. Homogeneity of mean data values for each treatment across replicate experiments was confirmed by one-tailed correlation analyses (nonnormal data: Spearman Rank; normal data: Pearson product moment) conducted within the Statistical Package for the Social Sciences (SPSS 11.0; SPSS Inc., Chicago, IL) $(r \geq 0.783 ; P=0.000)(42)$. The exception was that the number of mean data values for trichodiene synthase gene expression data was inadequate for such analysis. Correlations between wheat and barley data, and between wheat germination tests and stem inoculation seedling blight data, also were performed using one-tailed correlation analyses (nonnormal data: Spearman Rank; normal data: Pearson product moment). For normally distributed data (germination test data, gene expression data, and transformed soil inoculation tests seedling blight scores), treatment effects were compared using one-way analysis of variance with Post Hoc pairwise least significance difference comparisons $(P=0.050)$ within SPSS (42). The treatment effects within the nonnormally distributed data from stem inoculation seedling blight tests were assessed using the Kruskal-Wallis H test in SPSS (42).

\section{RESULTS}

Effect of microbial isolates and chitosan on the germination of wheat seedlings. Wheat seed (cv. GK-Othalom) inoculated with $F$. culmorum and treated with LB (positive control) failed to germinate. Treatment with chitosan or spore suspensions of the 31 fungal isolates did not ameliorate the effect of $F$. culmorum inoculation on wheat seedling germination (data not shown). But, 15 of the 151 bacteria tested had a positive effect on coleoptile growth; the coleoptile growth rate of seeds inoculated with any of these bacteria and with $F$. culmorum was $\geq 23 \%$ of that observed in negative control seeds treated with LB and $0.2 \%$ Tween 20 (Table 1). These 15 bacteria were tested for their ability to reduce coleoptile growth retardation caused by $F$. culmorum on a range of wheat cultivars commercially grown in Ireland in recent years (Table 1). In contrast to their effect on Hungarian cv. GKOthalom, Exiguobacterium sp. strain MKB 41, B. mycoides strain MKB 85, P. fluorescens strain MKB 90, and P. fluorescens strain MKB 156 and unidentified isolates MKB 55, MKB 159, and MKB 264 had very little or no effect on coleoptile growth of F. culmorum-inoculated seed of wheat cvs. Access, Marshal, Claire, Soisson, and Baldus (Table 1). P. fluorescens strain MKB 100 and strain MKB 249, P. frederiksbergensis strain MKB 202, Pseudomonas sp. strain MKB 158, Acinetobacter sp. strain MKB 121, Chryseobacterium sp. strain MKB 277, and the unidentified bacterial isolate MKB 25 exhibited more consistent ability to improve coleoptile growth of $F$. culmorum-inoculated seed of all six wheat cultivars (Table 1).

We also examined bacterial growth rate (CFU per hour) on germinating seeds of wheat cv. GK-Othalom. In these tests, we included the same 15 bacteria listed above and five unidentified bacteria (MKB 2, MKB 8, MKB 10, MKB 17, and MKB 24) that showed no ability in the screening trial to improve the germination rate of seedlings inoculated with $F$. culmorum. There was no significant correlation between their ability to ameliorate the effect of $F$. culmorum on germination and their growth rate on wheat seeds $(r=0.101 ; P>0.050)$. For example, $P$. fluorescens strain MKB 158 caused the greatest overall improvement in coleoptile growth rate of $F$. culmorum-inoculated seeds (mean improvement across the six cultivars, relative to plants inoculated with $F$. culmorum and treated with $\mathrm{LB}=60 \%$ ), but was among the slowest growing of the 15 potential biocontrol bacterial isolates tested (Fig. 1).

Effect of bacteria and chitosan on seedling blight of wheat and barley. Based on their performance in the in vitro germination test, seven bacterial isolates were included in the stem inoculation seedling blight tests (Fig. 2). Control plants treated with $0.2 \%$ Tween 20 and bacterial culture, LB broth, or alkalized acetic acid exhibited no disease symptoms and appeared healthy (data not shown). P. fluorescens strains MKB 100 and MKB 249, $P$. frederiksbergensis strain MKB 202, Pseudomonas sp. strain MKB 158, Chryseobacterium sp. strain MKB 277, and chitosan all significantly reduced Fusarium seedling blight disease symptoms on both wheat (cv. GK-Othalom) and barley (cv. Lux) by at least $23 \%$, relative to LB-treated control plants inoculated with F. culmorum (Fig. 2). The pseudomonads were more effective in reducing disease than Chryseobacterium sp. strain MKB $277(\geq 53$ and $\leq 46 \%$ reduction, respectively). Among the pseudomonads, P. fluorescens strain MKB 100 and chitosan were most effective in reducing Fusarium seedling blight disease symptoms on both wheat (cv. GK-Othalom) and barley (cv. Lux) (by 83 to 91\%; $P \leq$ 0.027), relative to LB-treated control plants inoculated with F. culmorum (Fig. 2). Unidentified bacterial isolate MKB 25, Acinetobacter sp. strain MKB 121, and P. fluorescens strain MKB 156 had no significant effect on the visual symptoms observed on either wheat or barley inoculated with F. culmorum. There was no significant correlation between the performance of the isolates in the germination test and stem base test on either wheat or barley $(r=0.157 ; P>0.050)$, but in these stem base inoculation experiments, there was a strong correlation between the results obtained for wheat and barley $(r=0.911 ; P<0.010)$.

Effect of Pseudomonas sp. strain MKB 158 on regulation of Fusarium mycotoxin biosynthesis. Expression of the Tri5 gene

TABLE 2. In vitro bacterial inhibition of Fusarium growth in dual culture plate tests

\begin{tabular}{|c|c|c|c|c|}
\hline \multirow{2}{*}{$\begin{array}{l}\text { Isolate } \\
\text { code }\end{array}$} & \multirow[b]{2}{*}{ Species $^{\mathrm{a}}$} & \multicolumn{3}{|c|}{$\begin{array}{l}\text { Relative growth inhibition } \\
\text { of Fusarium species }(\%)^{\mathrm{b}}\end{array}$} \\
\hline & & F. culmorum & F. graminearum & F. poae \\
\hline MKB 25 & ND & 0 & 0 & 0 \\
\hline $\operatorname{MKB} 41^{c}$ & Exiguobacterium sp. & 0 & 0 & 0 \\
\hline MKB 55 & $\mathrm{ND}$ & 0 & 0 & 0 \\
\hline MKB 74 & $\begin{array}{l}\text { Low } \mathrm{G}+\mathrm{C} \text { gram- } \\
\text { positive bacterium }\end{array}$ & 0 & 0 & 0 \\
\hline MKB 85 & Bacillus mycoides & 0 & 0 & 0 \\
\hline MKB 90 & $\begin{array}{l}\text { Pseudomonas } \\
\text { fluorescens }\end{array}$ & 34 & 52 & 38 \\
\hline MKB 100 & P. fluorescens & 0 & 0 & 0 \\
\hline MKB 121 & Acinetobacter sp. & 0 & 0 & 0 \\
\hline MKB 156 & P. fluorescens & 33 & 78 & 66 \\
\hline MKB 158 & Pseudomonas sp. & 0 & 0 & 0 \\
\hline MKB 159 & ND & 0 & 0 & 0 \\
\hline MKB 202 & P. frederiksbergensis & 0 & 0 & 0 \\
\hline MKB 249 & P. fluorescens & 0 & 0 & 0 \\
\hline MKB 264 & ND & 0 & 0 & 0 \\
\hline MKB $277^{\mathrm{c}}$ & Chryseobacterium sp. & 0 & 0 & 0 \\
\hline
\end{tabular}

${ }^{a}$ Identified based on partial 16S rDNA sequence. ND = not determined.

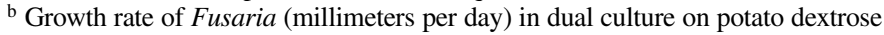
agar (PDA), relative to growth rate in the presence of Luria-Bertani broth.

${ }^{c}$ Did not grow on PDA. 


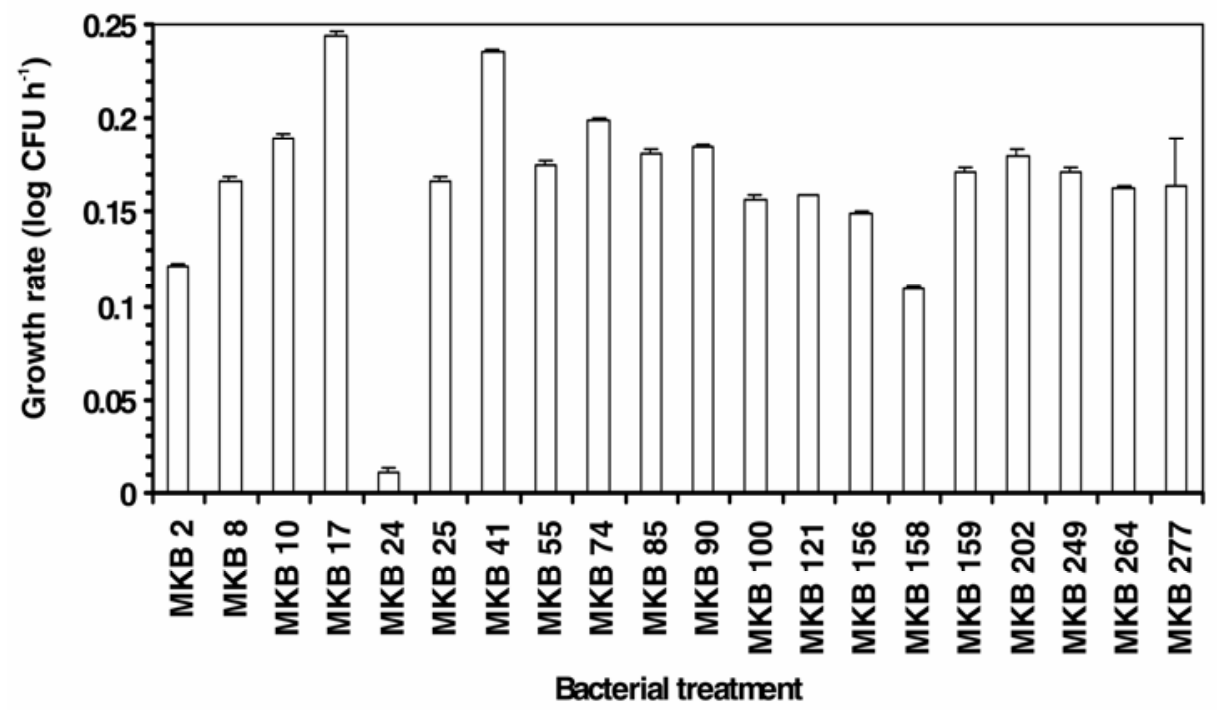

Fig. 1. Growth rates of bacteria on germinating seed of wheat cv. GK-Othalom on filter paper that overlayed potato dextrose agar. At both 6 and $24 \mathrm{~h}$ postinoculation, bacteria were recovered from seed into $1 \mathrm{ml}$ of $0.9 \% \mathrm{NaCl}$ and the growth rate was expressed as the $\log \mathrm{CFU} \mathrm{h}{ }^{-1}$. Bacteria: MKB 2, MKB 8, MKB 10, MKB 17, and MKB 24, unidentified nonpotential biocontrol isolates; MKB 25, MKB 55, MKB 159, and MKB 264, unidentified potential biocontrol bacteria; MKB 90, MKB 100, MKB 156, and MKB 249, Pseudomonas fluorescens; MKB 41, Exiguobacterium sp.; MKB 74, low G+C gram-positive bacterium; MKB 85, Bacillus mycoides; MKB 121, Acinetobacter sp.; MKB 158, Pseudomonas sp.; MKB 202, P. frederiksbergensis; and MKB 277, Chryseobacterium sp. Bars indicate standard error of the mean $\left(\mathrm{LSD}_{0.05}=0.027\right)$.

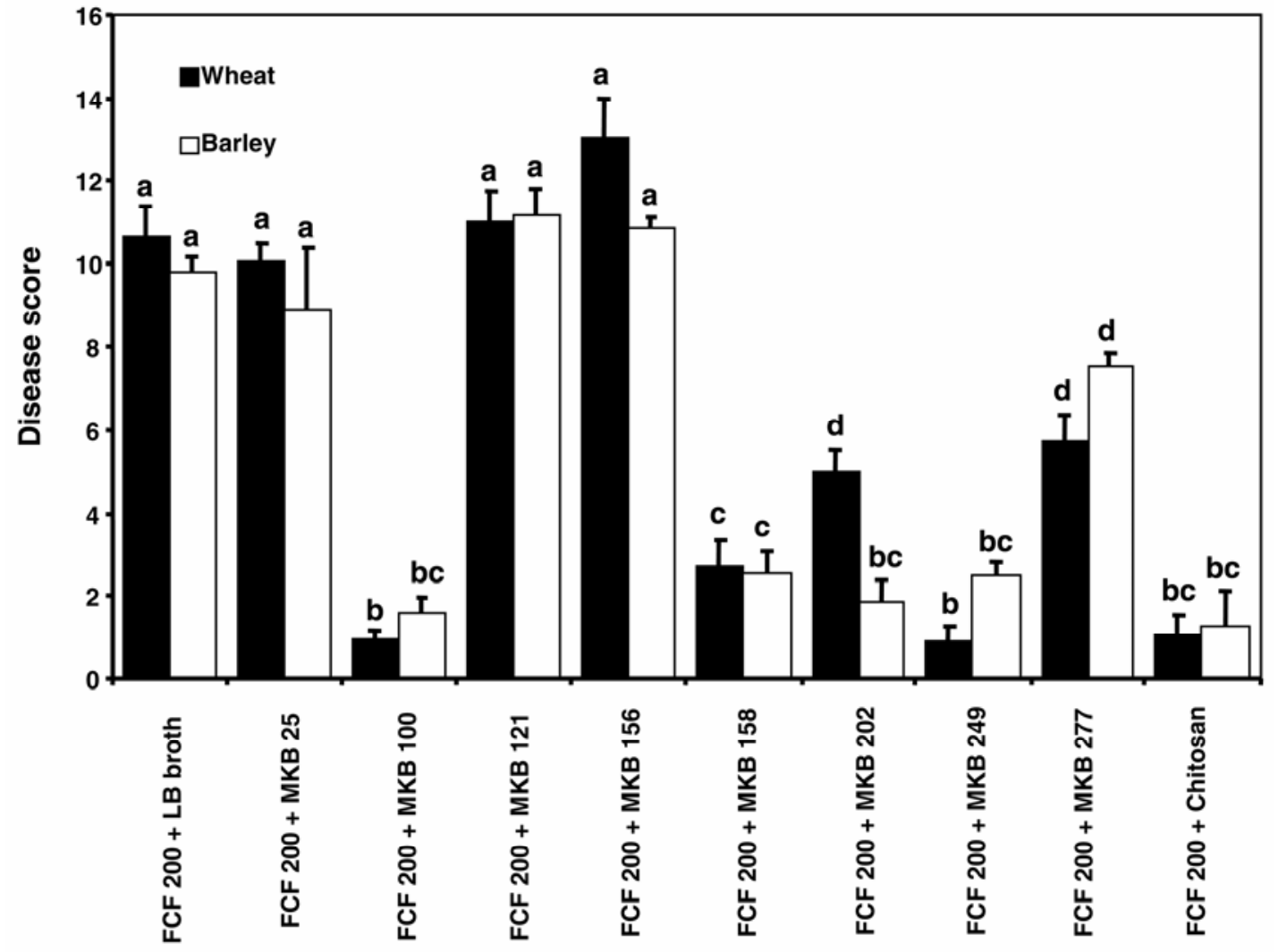

Treatment

Fig. 2. Disease symptom development on wheat cv. GK-Othalom and barley cv. Lux stem bases that were coinoculated with Fusarium culmorum strain FCF 200 and either bacteria or chitosan. Visual disease symptoms were assessed 12 days postinoculation. Seedling blight disease symptoms were scored as product of lesion length $(\mathrm{cm})$ by lesion color (lesion color scale: 0 , no disease; 1 , very slight brown necrosis; 2 , slight/moderate brown necrosis; 3 , extensive brown necrosis; and 4, extensive black necrosis) (32). Bacterial codes: MKB 25, unidentified bacterium; MKB 100, MKB 156, and MKB 249, Pseudomonas fluorescens; MKB 121, Acinetobacter sp.; MKB 158, Pseudomonas sp.; MKB 202, P. frederiksbergensis; and MKB 277, Chryseobacterium sp. Bars indicate standard error of the mean; columns with the same letters are not significantly different $(P>0.050)$ based on a Kruskal-Wallis $\mathrm{H}$ test. 
from Fusarium was significantly reduced in stem bases of wheat (cv. GK-Othalom) coinoculated with Pseudomonas sp. strain MKB 158 and $F$. culmorum, relative to the expression in LB-treated stem bases inoculated with $F$. culmorum $(0.16$ and 0.25 relative to $\beta$-tubulin gene expression, respectively; $P=0.019)$. No Tri5 expression was observed in stem bases subjected to control treatments $(0.2 \%$ Tween 20 plus either bacterial culture or LB broth).

Mode of action of potential biocontrol agents. Of the 15 bacterial isolates tested, only $P$. fluorescens strains MKB 90 and MKB 156 had a direct inhibitory effect on the growth of $F$. culmorum strain FCF200, F. graminearum strain HUGR9, and $F$. poae strain HUPO3 in dual culture plate tests (Table 2). Exiguobacterium sp. strain MKB 41 and Chryseobacterium sp. strain MKB 277 did not grow on the dual culture medium (PDA).

Both wheat (cv. GK-Othalom) and barley (cv. Lux) were grown in soils amended with either Pseudomonas sp. strain MKB 158, $P$. fluorescens strain MKB 249, their culture filtrates, or chitosan prior to stem base inoculation with $F$. culmorum. Control plants grown in soil amended with either bacterial culture, bacterial culture filtrate, LB broth, or alkalized acetic acid exhibited no disease symptoms and appeared healthy (data not shown). For both wheat and barley, the levels of disease control observed on plants grown in soils amended with either Pseudomonas sp. strain MKB 158 or P. fluorescens strain MKB 249 were similar to those observed when these bacteria were coinoculated onto stem bases with $F$. culmorum (Figs. 2 and 3). For example, P. fluorescens strain MKB 158 caused a 75 and $72 \%$ reduction in the wheat coinoculation and soil amendment tests, respectively. Soil amendment with culture filtrates of Pseudomonas sp. strain MKB 158 or $P$. fluorescens strain MKB 249 also significantly reduced seedling blight disease of both wheat and barley by $\geq 44 \%$ (Fig. 3) $(P=$ 0.000). Although, overall there was a strong correlation between the wheat and barley results in the soil amendment experiments $(r=0.788 ; P<0.010)$, culture filtrates were less effective against wheat than against barley seedling blight disease (Fig. 3). Chito- san was significantly less effective as a soil amendment than it was in coinoculation tests in controlling wheat seedling blight disease (reduction in disease symptoms relative to LB-treated plants inoculated with $F$. culmorum $=31$ and $90 \%$, respectively). Combining different bacteria and chitosan did not improve the level of disease suppression (Fig. 3).

Effect of bacteria on the expression of a wheat class III POX gene. $P O X$ was expressed in wheat stem base tissue treated with $0.2 \%$ Tween 20 and LB broth (negative control); expression of $P O X$ was quantified relative to the expression of the wheat housekeeping gene GAPDH (Fig. 4). Stem base treatment with the pathogen $F$. culmorum plus LB, or with $0.2 \%$ Tween 20 and $P$. fluorescens strain MKB 156, resulted in significant increases in $P O X$ expression, relative to that in negative control plants $(65 \%$, $P=0.000)$. While the $23 \%$ increase in $P O X$ expression in stem bases treated with $0.2 \%$ Tween 20 and Pseudomonas sp. strain MKB 158, relative to that in negative control plants, was not significant $(P=0.069)$, this bacterium stimulated $P O X$ expression when coinoculated with $F$. culmorum (by $35 \%$, relative to that in LB-treated, F. culmorum-inoculated tissue; $P \leq 0.050$; Fig. 4). In contrast, $P O X$ gene expression was $34 \%$ lower in plants coinoculated with $P$. fluorescens strain MKB 156 and F. culmorum $(P<0.050)$.

\section{DISCUSSION}

Strains of $P$. fluorescens (MKB 100 and MKB 249), P. frederiksbergensis strain MKB 202, and Pseudomonas sp. strain MKB 158 were effective in ameliorating the negative effects of $F$. culmorum on seedling germination of six wheat cultivars and on stem base infection of wheat cv. GK-Othalom and barley cv. Lux. Unlike other bacteria tested, these appeared not to exhibit host genotype or tissue specificity. The host genotype-dependent nature of the biocontrol efficacy of other bacteria in the seed germination tests suggests that potential biocontrol agents should be tested against a range of host cultivars.

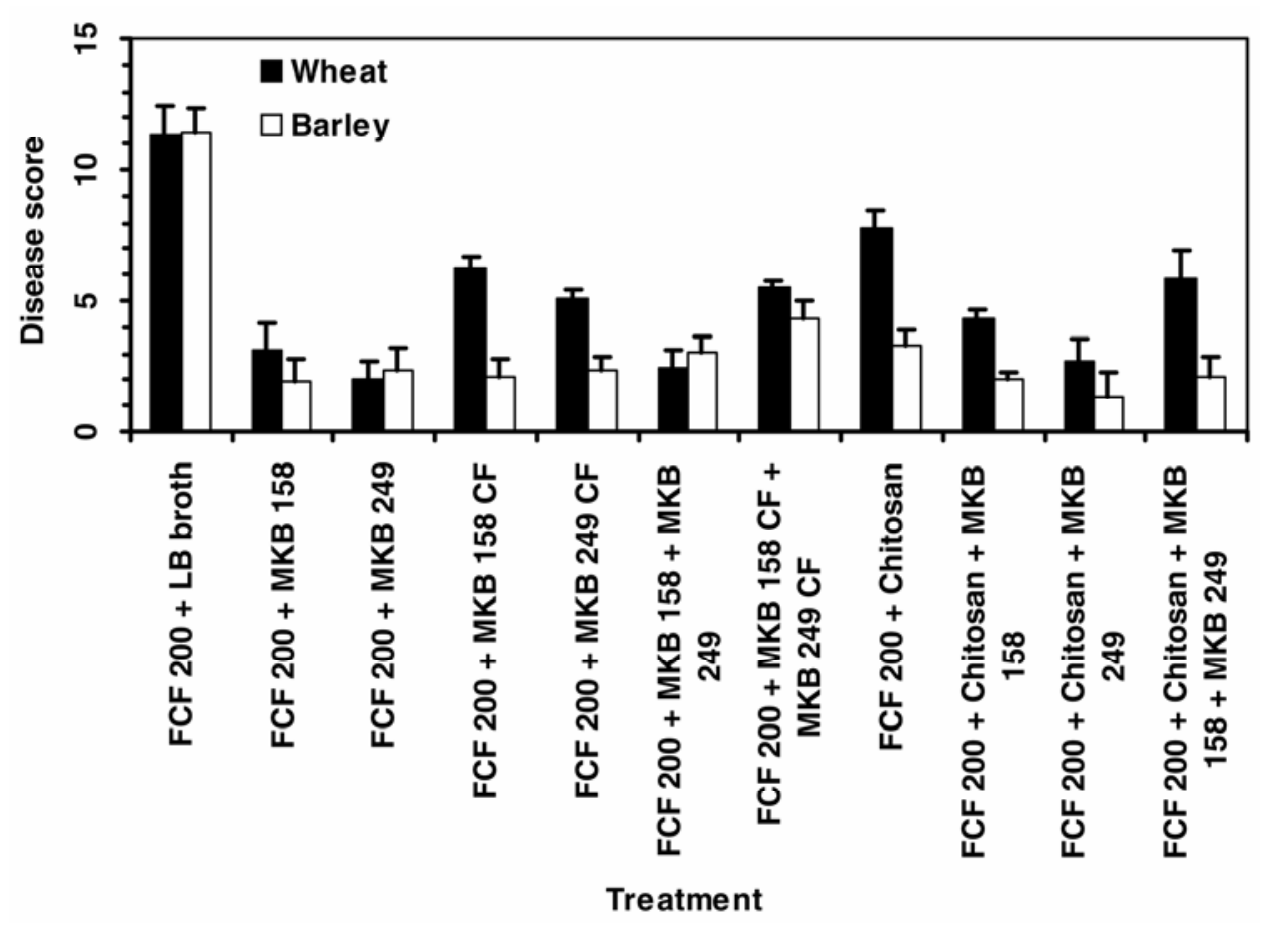

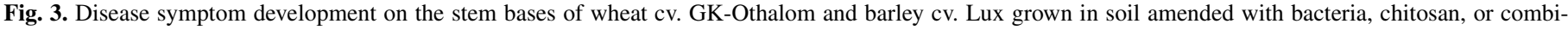

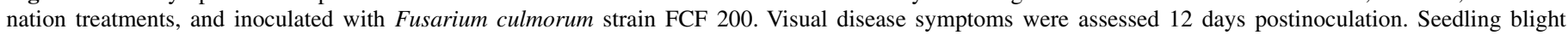

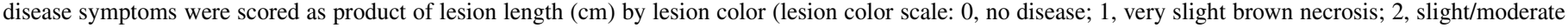

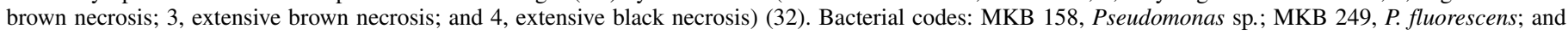
$\mathrm{CF}$, culture filtrate. Bars indicate standard error of the mean $\left(\operatorname{LSD}_{0.05}=2.8\right)$. 
The Tri5 gene encodes trichodiene synthase that catalyzes the first step of the trichothecene mycotoxin biosynthetic pathway in trichothecene-producing Fusaria (15). Reduced Tri5 gene expression in plants coinoculated with $F$. culmorum and Pseudomonas sp. strain 158 compared with plants inoculated with F. culmorum and treated with LB broth probably reflects the lower fungal biomass levels present in the former. It would be interesting to determine the relationship between Tri5 gene expression levels and fungal biomass; this would enable us to determine if this gene was differentially regulated in response to the activity of the biocontrol agent. Though biocontrol Cryptococcus species reduced FHB severity by 50 to $60 \%$, Khan et al. (26) found that this did not result in a significant reduction in the level of the trichothecene mycotoxin deoxynivalenol produced by $F$. graminearum in grain.

Microbial biocontrol agents may act against plant pathogens in three different ways: competition for space and/or nutrients (e.g., for iron by fluorescent pseudomonads); direct antagonism; or induction of host plant defense mechanisms (35). Of the four potential biocontrol isolates mentioned above ( $P$. fluorescens strain MKB 100, Pseudomonas sp. strain MKB 158, P. frederiksbergensis strain MKB 202, and P. fluorescens strain MKB 249), none showed direct antifungal activity against Fusarium isolates in vitro. But, dual culture plate tests were only conducted on PDA; therefore, these results should be viewed with caution. Future studies will determine if they show any inhibitory activity on other, less nutrient-rich media. The in vitro growth rates of these bacteria on germinating wheat seeds were not significantly higher than those of bacteria that did not exhibit biocontrol capability. Four of the potential biocontrol bacteria are fluorescent pseudomonads and produced fluorescent siderophores in King's B agar (27), which might have contributed to their in planta biocontrol ability. Siderophores may help in competition for iron (1) and/or induction of systemic disease resistance in the plant (28). Moreover, the fact that soil amendment with either Pseudomonas sp. strain MKB 158 or $P$. fluorescens strain MKB 249 or their culture filtrates reduced both Fusarium seedling blight of wheat (cv. GKOthalom) and barley (cv. Lux) caused by stem base inoculation of F. culmorum suggests that perhaps metabolite(s) from these bacteria activated a systemic defense against the pathogen. Pieterse et al. (36) reported systemic resistance toward both the fungal root pathogen $F$. oxysporum f. sp. raphani and the bacterial leaf pathogen $P$. syringae pv. tomato in Arabidopsis induced by the soilapplied biocontrol bacterium $P$. fluorescens strain WCS417r.

Class III peroxidases are plant-specific oxido-reductases involved in lignification, suberization, auxin catabolism, wound healing, and defense against pathogen infection (22). Recent research in our laboratory (K. I. Ansari and F. M. Doohan, personal communication) identified a gene encoding a wheat class III peroxidase that was up-regulated in wheat roots and heads in response to Fusarium infection. This gene had high amino acid divergence from wheat peroxidases in the GenBank database. Increased activation of this gene by Pseudomonas sp. strain MKB 158 in the presence of $F$. culmorum compared with activation by the pathogen alone is further evidence that plant defense genes are activated by this bacterium. P. fluorescens strain MKB 156 that exhibited direct antifungal activity, but host genotype specificity in its biocontrol capacity, did not induce overexpression of this gene. Chen et al. (13) also found that certain peroxidase isomers accumulated in cucumber roots in response to inoculation with biocontrol Pseudomonas species; these isomers also accumulated in response to the root pathogen Pythium aphanidermatum. Studies suggest that at least some peroxidase genes are induced via different signal transduction pathways from those of other

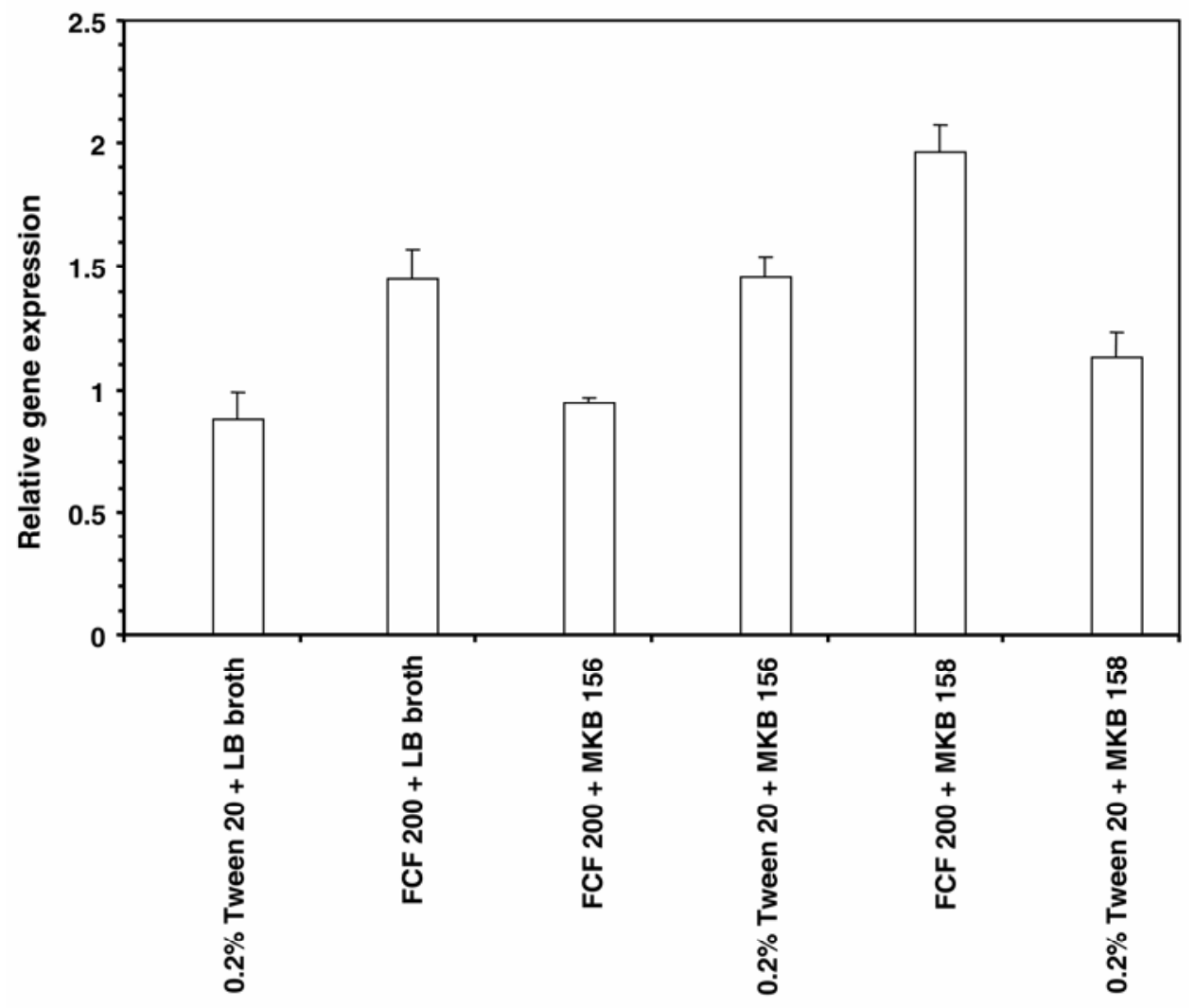

Treatment

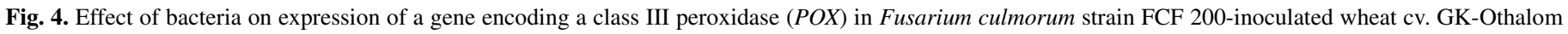

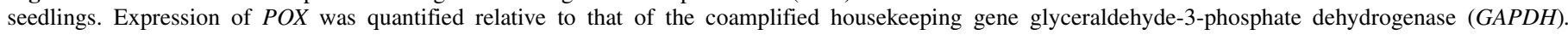
Bacterial codes: MKB 158, Pseudomonas sp.; and MKB 249, P. fluorescens. Bars indicate standard error of the mean $\left(\mathrm{LSD}_{0.05}=0.31\right)$. 
known defense-related genes (22). Future studies in our laboratory will analyze the signals inducing the expression of the wheat class III peroxidase studied in this research.

Chitosan has been shown to significantly reduce Fusarium seedling blight disease of wheat caused by seedborne $F$. graminearum (40). We found that even lower doses (1,000 versus 2,000 to $8,000 \mathrm{ppm}$ ) were effective in reducing $F$. culmorum seedling blight of wheat, both as a stem base treatment and as a soil amendment. Chitosan exhibited direct antifungal activity against Candida albicans, F. oxysporum, Aspergillus fumigatus, Aspergillus parasiticus (43), and Alternaria alternata f. sp. lycopersici (8). In this study, chitosan did not inhibit the mycelial growth of $F$. culmorum, $F$. graminearum, or $F$. poae, but it is possible that it inhibits conidial germination, and this was not assessed in our dual culture tests. Chitosan induced systemic host resistance to F. culmorum, as seen in the soil amendment seedling blight tests; to our knowledge, this is the first report on the ability of chitosan to induce systemic resistance in wheat and barley plants against exogenous $F$. culmorum inoculum. There are reports on chitosan inducing systemic resistance against different plant pathogens, including fungi, in a plant species-dependent manner $(3,18,21)$. Chitosan is known to be an early inducer of jasmonic acid (JA) (15 to $60 \mathrm{~min}$ postapplication) in rice leaf sections, implying a role for JA downstream of a "pathogen-derived" signal in rice (39). Soil amendment with chitosan or with culture filtrate of either Pseudomonas sp. strain MKB 158 or P. fluorescens strain MKB 249 was less effective in reducing Fusarium seedling blight of wheat than of barley. This may be due to host-specific biocontrol efficacy of metabolites, but it is more likely due to variations in root architecture or composition that affect elicitor or metabolite uptake efficacy.

In conclusion, we have found that chitosan and isolates of Pseudomonas spp. are effective in reducing the severity of Fusarium seedling blight of wheat and barley under controlled environment conditions. Future work will test the efficacy of these biocontrol agents in controlling seedling blight and FHB of wheat and barley under field conditions. Microarray analysis is currently being conducted in order to better understand the molecular phenomena underlying the systemic resistance toward Fusarium seedling blight of barley induced by the potential biocontrol agents.

\section{ACKNOWLEDGMENTS}

This work was supported by the Irish Department of Agriculture, Food and Rural Development Research Stimulus Fund (RSF65) as part of the National Development Plan.

\section{LITERATURE CITED}

1. Bakker, P. A. H. M., Raaijmakers, J. M., and Schippers, B. 1993. Pages 269-282 in: Iron Chelation in Plants and Soil Microorganisms. L. L. Barton and B. C. Hemming, eds. Academic Press, San Diego, CA.

2. Bakker, P. A. H. M., Van Peer, R., and Schippers, B. 1991. Suppression of soil-borne plant pathogens by fluorescent pseudomonas: Mechanisms and prospects. Pages 217-230 in: Biotic Interactions and Soil-Borne Diseases, Developments in Agricultural and Managed-Forest Ecology. A. B. R. Beemster, G. J. Bollen, M. Gerlagh, M. A. Ruissen, B. Schippers, and A. Tempel, eds. Elsevier Scientific Publishers, Amsterdam, The Netherlands.

3. Barka, E. A., Eullaffroy, P., Clement, C., and Vernet, G. 2004. Chitosan improves development, and protects Vitis vinifera L. against Botrytis cinerea. Plant Cell Rep. 22:608-614.

4. Bello, G. M. D., Monaco, C. I., and Simon, M. R. 2002. Biological control of seedling blight of wheat caused by Fusarium graminearum with beneficial rhizosphere microorganisms. World J. Microbiol. Biotechnol. 18:627-636.

5. Benhamou, N., Kloepper, W., and Tuzun, S. 1998. Induction of resistance against Fusarium wilt of tomato by combination of chitosan with an endophytic bacterial strain: Ultrastructure and cytochemistry of the host response. Planta 204:153-168.

6. Berg, G., Roskot, N., Steidle, A., Eberl, L., Zock, A., and Smalla, K. 2002. Plant-dependent genotypic and phenotypic diversity of antagonistic rhizobacteria isolated from different Verticillium host plants. Appl. Environ. Microbiol. 68:3328-3338.

7. Bernard, P., Romond, C., and Bhatnagar, T. 1995. Biological control of Pythium mamillatum causing damping-off of cucumber seedlings by a soil bacterium, Bacillus mycoides. Microbiol. Res. 150:71-75.

8. Bhaskara, M. V. R., Arul, J., Ait Barka, E., Richard, C., Angers, P., and Castaigne, F. 1998. Effect of chitosan on growth and toxin production by A. alternata f. sp. lycopersici. Biocontrol Sci. Technol. 8:33-43.

9. Brennan, J. M., Leonard, G., Cooke, B. M., and Doohan, F. M. 2005. Effect of temperature on head blight of wheat caused by Fusarium culmorum and $F$. graminearum. Plant Pathol. 54:156-160.

10. Brennan, J. M., van Maanen, A., Egan, D., Cooke, B. M., and Doohan, F. M. 2003. Effect of temperature on growth and in vitro pathogenicity of European phytopathogenic Fusarium species causing head blight disease of wheat. Eur. J. Plant Pathol. 109:577-587.

11. Buyer, J. S., Roberts, D. P., and Cohen, E. R. 2002. Soil and plant effects on microbial community structure. Can. J. Microbiol. 48:955-964.

12. Chang, S., Puryer, J., and Cairney, J. 1993. A simple and efficient method for isolating RNA from pine trees. Plant Mol. Biol. Rep. 11:113-116.

13. Chen, C., Belanger, R. R., Benhamou, N., and Paulitz, T. C. 2000. Defense enzymes induced in cucumber roots by treatment with plant growthpromoting rhizobacteria (PGPR) and Pythium aphanidermatum. Physiol. Mol. Plant Pathol. 56:13-23.

14. De Boer, M., Bom, P., Kindt, F., Keurentjes, J. J. B., van der Sluis, L., van Loon, L. C., and Bakker, P. A. H. M. 2003. Control of Fusarium wilt of radish by combining Pseudomonas putida strains that have different disease-suppressive mechanisms. Phytopathology 93:626-632.

15. Desjardins, A. E., Hohn, T. M., and McCormick, S. P., 1993. Trichothecene biosynthesis in Fusarium species: Chemistry, genetics, and significance. Microbiol. Rev. 57:595-604.

16. Doohan, F. M., Weston, G., Rezanoor, H. N., Parry, D. W., and Nicholson, P. 1999. Development and use of a reverse transcription-PCR assay to study expression of Tri5 by Fusarium species in vitro and in planta. Appl. Environ. Microbiol. 65:3850-3854.

17. Emmert, E. A. B., and Handelsman, J. 1999. Biocontrol of plant disease: A (Gram-) positive perspective. FEMS Microbiol. Lett. 171:1-9.

18. Faoro, F., Sant, S., Iriti, M., Maffi, D., and Appiano, A. 2001. Chitosanelicited resistance to plant viruses: A histochemical and cytochemical study. Pages 57-62 in: Chitin Enzymology. R. A. A. Muzzarelli, ed. AtecEdizioni, Grottammare, Italy.

19. Gozzo, F. 2003. Systemic acquired resistance in crop protection: From nature to a chemical approach. J. Agric. Food Chem. 51:4487-4503.

20. Hadwiger, L. A. 1994. Chitosan as crop growth regulator. Pages 99-109 in: Proceedings of the Asia-Pacific Chitin and Chitosan Symposium. Universiti Kebangsaan Malaysia, Bang, Malaysia.

21. Hadwiger, L. A., Beckman, J. M., and Adams, M. J. 1981. Localization of fungal components in the pea-Fusarium interaction detected immunochemically with anti-chitosan and anti-fungal cell wall antisera. Plant Physiol. 67:170-175.

22. Hiraga, S., Sasaki, K., Ito, H., Ohashi, Y., and Matsui, H. 2001. A large family of class III plant peroxidases. Plant Cell Physiol. 42:462-468.

23. Hohn, T. M., and Beremand, P. D. 1989. Isolation and nucleotide sequence of sesquiterpene cyclase gene from the trichothecene-producing fungus Fusarium sporotrichioides. Gene 79:131-138.

24. Humphreys, J., Cooke, B. M., and Storey, T. 1998. Effects of seed-borne Microdochium nivale on establishment and population density at harvest of winter-sown oats. Plant Var. Seeds 11:83-90.

25. Johansson, P. M., Johnsson, L., and Gerhardson, B. 2003. Suppression of wheat-seedling diseases caused by Fusarium culmorum and Microdochium nivale using bacterial seed treatment. Plant Pathol. 52:219227.

26. Khan, N. I., Schisler, D. A., Boehm, M. J., Lipps, P. E., and Slininger, P. J. 2004. Field testing of antagonists of Fusarium head blight incited by Gibberella zeae. Biol. Control 29:245-255.

27. King, E. O., Ward, M. K., and Raney, D. E. 1954. Two simple media for the demonstration of pyocyanin and fluorescein. J. Lab. Clin. Med. 44:301-307.

28. Leeman, M., Den Ouden, F. M., Van Pelt, J. A., Dirkx, F. P. M., Steiji, H., Bakker, P. A. H. M., and Schippers, B. 1996. Iron availability affects induction of systemic resistance to Fusarium wilt of radish by Pseudomonas fluorescens. Phytopathology 86:149-155.

29. Mao, W., Lewis, J., Hebber, P., and Lumsden, R. 1997. Seed treatment with a fungal or a bacterial antagonist for reducing corn damping-off caused by species of Pythium and Fusarium. Plant Dis. 81:450-454.

30. Mesterhazy, A. 1983. Breeding wheat for resistance to Fusarium graminearum and F. culmorum. Z. Pflanzenzuecht. 91:295-311.

31. Moenne-Loccoz, M., Naughton, P., Higgins, J., Powell, B. O., and O'Gara, F. 1999. Effect of inoculum preparation and formulation on survival and biocontrol efficacy of Pseudomonas fluorescens F113 Y. J. Appl. Microbiol. 86:108-116. 
32. Nicholson, P., Simpson, D. R., Weston, G., Rezanoor, H. N., Lees, A. K., Parry, D. W., and Joyce, D. 1998. Detection and quantification of Fusarium culmorum and Fusarium graminearum in cereals using PCR assays. Physiol. Mol. Plant Pathol. 53:17-37.

33. Parry, D. W., Jenkinson, P., and McCleod, L. 1995. Fusarium ear blight (scab) in small grain cereals, a review. Plant Pathol. 44:207-238.

34. Pedersen, E. A., Reddy, M. S., and Chakravarty, P. 1999. Effect of three species of bacteria on damping-off, root rot development, and ectomycorrhizal colonization of lodgepole pine and white spruce seedlings. Eur. J. For. Pathol. 29:123.

35. Pieterse, C. M. J., Pelt, J. A. V., Wees, S. C. M. V., Ton, J., Kloostererziel, K. M. L., Keurentjes, J. J. B., Verhagen, B. W. M., Knoester, M., Sluis, I. V. D., Bakker, P. A. H. M., and Loon, L. C. V. 2001. Rhizobacteriamediated induced systemic resistance: Triggering, signaling and expression. Eur. J. Plant Pathol. 107:51-61.

36. Pieterse, C. M. J., Wees, S. C. M. V., Hoffland, E., Pelt, J. A. V., and Loon, L. C. V. 1996. Systemic resistance in Arabidopsis induced by biocontrol bacteria is independent of salicylic acid accumulation and pathogenesis-related gene expression. Plant Cell 8:1225-1237.

37. Pirgozliev, S. R., Edwards, S. G., Hare, M. C., and Jenkinson, P. 2003. Strategies for the control of Fusarium head blight in cereals. Eur. J. Plant Pathol. 109:731-742.

38. Raaijmakers, J. M., and Weller, D. M. 1998. Natural plant protection by, 1,4-diacetylphloroglucinol-producing Pseudomonas spp. in take-all decline soils. Mol. Plant-Microbe Interact. 10:761-768.

39. Rakwal, R., Tamogami, S., Agrawal, G. K., and Iwahashi, H. 2002. Octadecanoid signaling component "burst" in rice (Oryza sativa L.) seedling leaves upon wounding by cut and treatment with fungal elicitor chitosan.
Biochem. Biophys. Res. Commun. 295:1041-1045.

40. Reddy, M. V. B., Arul, J., Angers, P., and Couture, L. 1999. Chitosan treatment of wheat seeds induces resistance to Fusarium graminearum and improves seed quality. J. Agric. Food Chem. 47:1208-1216.

41. Sambrook, J., Fritsch, E. F., and Maniatis, T. 1989. Molecular Cloning: A Laboratory Manual. 2nd ed. Cold Spring Harbor Laboratory, Cold Spring Harbor, NY.

42. Snedecor, G. W., and Cochran, W. G. 1980. Statistical Methods. The Iowa State University Press, IA.

43. Tsai, G. J., Su, W. H., Chen, H. C., and Pan, C. L. 2002. Antimicrobia activity of shrimp chitin and chitosan from different treatments and applications of fish preservation. Fish. Sci. 68:170-177.

44. Whipps, J. M., and Lumsden, R. D. 2001. Commercial use of fungi as plant disease biological control agents: Status and prospects. Pages 9-22 in: Fungi as Biocontrol Agents: Progress, Problems and Potential. T. M. Butt, C. Jackson, and N. Magan, eds. CABI Publishing, Wallingford, UK.

45. Wiese, M. V. 1977. Compendium of Wheat Diseases. The American Phytopathological Society, St. Paul, MN.

46. Wong, L. S. L., Tekauz, A., Leslie, D., Abramson, D., and McKenzie, R. I. H. 1992. Prevalence, distribution and importance of Fusarium head blight in winter in Manitoba. Can. J. Plant Pathol. 14:233-238.

47. Yu, G. Y., and Muehlbauer, G. J. 2001. Benzothiadiazole-induced gene expression in wheat spikes does not provide resistance to Fusarium head blight. Physiol. Mol. Plant Pathol. 59:129-136.

48. Zuppini, A., Baldan, B., Millioni, R., Favaron, F., Navazio, L., and Mariani, P. 2004. Chitosan induces $\mathrm{Ca}^{2+}$-mediated programmed cell death in soybean cells. New Phytol. 161:557-568. 